To cite this article: Aishat Joyce Egbunu (2020) Relationship Between Information Communication Technology and Book Production in Publishing Industry in Nigeria. Information Impact: Journal of Information and Knowledge Management, 11:2, 31-34, DOI: dx.doi.org/10.4314/iijikm.v11i2.3

To link to this article: https://dx.doi.org/10.4314/iijikm.v11i2.3

\title{
Relationship Between Information Communication Technology and Book Production in Publishing Industry in Nigeria
}

\author{
Aishat Joyce Egbunu \\ Samuel Ogbemudia Library, University of Abuja, Nigeria
}

\begin{abstract}
The study investigated the correlation between information communication technology and book production in publishing industry in Nigeria. Two forms of relationships were examined such as relationship between the application of communication facilities and book production and relationship between the application of technology facilities and book production in Nigeria. Null hypotheses were formulated thus: "There is no significant relationship between the application of communication facilities and book production in Nigeria and there is no significant relationship between application of technology facilities and book production in Nigeria." Survey research design was adopted for this study. The subject of the study consisted of all staff of the ten selected publishing industries in Nigeria, but a total of five hundred and forty six (546) personnel were sampled for the study using purposive sampling technique. It was discovered that, there was a significant relationship between the applications of communication and technology facilities in book production in Nigeria. The findings revealed that, the publishers had accepted and adopted the use of communication and technology facilities in Nigeria publishing industry, and had improved quality of production and increased productivity of books. Based on the findings, recommendations were proffered.
\end{abstract}

Keywords ICT, Utilization, Book Production

Publishing Industry,, Library Materials

CONTACT Egbunu, A. J. aishat.egbunu@uniabuja.edu.ng. Samuel Ogbemudia Library, University of Abuja

2020 The Author Published with License by Information Impact 


\section{Introduction}

The last two decades had witnessed the global interaction and application of ICT facilities in the provision of information service delivery. Aina (2004) and Abubakar (2010) defined ICT as a term used to describe the items or equipment and computer programs that allow users to access, retrieve, store, organize, manipulate and present information of different kinds and for different purposes by electronic means. In effect, it embraces all the technologies that enable the handling of information and facilitate different forms of communication between man and electronic systems such as phones, computers, networks, radios, satellite systems among others. Using ICT facilities in book production, has great impact on various processes of publishing. With Internet, printing-on-demand and e-book are the main drivers of change from the way books are published, distributed, sold and read. The book industry has benefited from the development of ICT in great measure. Book that will formerly take years to produce can now be produced in a few months. This has brought about electronic publishing, books that are available on CD-ROM and a lots of titles are available online. Today, with ICT, physical distance is no longer a barrier. Disseminating information has become a lot easier with the use of ICT facilities. Other benefits includes: enhanced performance (speed, skills and quality), improvement in communication, improvement in picture resolution and general graphics, reduced cost of production, better page layout, good image, high rating, and realization of corporate goals (Ehikhamenor, 2003).

Book production refers to the processes that is required to turn a manuscript into a final printed product or e-book. The processes includes editing, design, formatting, printing and e-book conversion. The primary purpose of books is to inform and educate the reading public through printed media. It also helps in the preservation and dissemination of knowledge in every literate society. In other words, publishing basically involves the activity of selection, preparation and marketing of information resources.

It is good to note that, publishing industry has been in existence before the coming of the Europeans. Then, messages were sent through town criers and talking drums. Also, early involvement of missionaries came into play, where published works were mostly on religious, literature, government publications and school textbooks meant for government and mission schools (Egbunu, 2004). By 1830, various printing and bookshop sprang up in Nigeria due to the encouragement received by the missionaries, and the publishing industry then, were categorize into three educational levels: primary, secondary and tertiary institutions. Other publications like journals, newspapers, magazines, posters, recreational materials among others were produced. Bishop Ajayi Crother was the pioneer in this area and did a lot of works from 1848-1856. Notable of is works were: translation of the Bible, book of common prayers, arithmetic tables and primers, grammar books and readers, dictionaries among others. Other notable contributors to publishing in Nigeria includes Yoruba Literary Society from 1887-1921. However, commercial book publishing had its origin in book marketing ventures by British companies like Oxford, University press, Evans, Nelson and Longman who sold 
books written by other nations. By 1927-1961 individual publishing came into limelight. Though, their publications were still on religion and folktales with publishing industry established all over Nigeria. In order to meet up with the demand for reading materials to reflect the content of the curriculum, the British publishing houses were compelled to modify their market policy towards meeting rudiments of the local publishers. Furthermore, the development of political, social and educational advancement in Nigeria led to the diversification of market which in turn support the local publishing industry. This period equally paved ways for writing serious textbooks, fictions, and non-fictions for highly educated people (Egbunu, 2004).

With regards to current trend in book production in Nigeria, the publishing industry is yet to attain the best practices like their foreign counterparts. The level of production is still inadequate compare to the demand by the society. However, with the application of ICT facilities in publishing industry, there is a little improvement in production especially in areas of e-resources. It has been observed that, the provision of adequate information resources from publishing industry has been inadequate for Nigerians and the publishers are finding it difficult to communicate effectively, produce and distribute sufficient information resources needed by the populace. The objective of the publishers is to provide quality books to meet the ever-growing demand for books. This therefore calls for effective utilization of ICT facilities to bring about the improvement in the book production in Nigeria. Perhaps, this could be attributed to underutilization of ICT facilities, slow acceptance and adoption of the facilities, as well as absence or inadequate skills to operate the ICT facilities and equipment. It was against this background that the study investigated the relationship between ICT and book production in publishing industries in Nigeria.

\section{Objectives of the Study}

The aim of the study is to find out the relationship between Information Communication Technology and book production in publishing industry in Nigeria. However, the specific objectives of the studies are to:

1. Find out the relationship between the utilization of information communication facilities in book production in Nigeria.

2. Examine the level of Information technology facilities use in book production by publishing industries in Nigeria.

\section{Research Questions}

To effectively conduct this study, the following research questions were formulated to guide the study.

1. What is the relationship between the information communication facilities in book production in Nigeria?

2. What is the level of information technology facilities use in book production in Nigeria publishing industries? 


\section{Hypotheses}

The following null hypotheses were tested at 0.05 level of significance in this study:

1. There is no significant relationship between the utilization of Communication facilities and Book Production in Nigeria.

2. There is no Significant Relationship between the Utilization of Technology facilities and Book Production in Nigeria.

\section{Theoretical Framework of the Study}

The theoretical framework for this study was anchored on the Utilization of Information Communication Technologies system implementation and adoption in publishing industry. The relevant theories that were examined were Technology Acceptance Model (Davies et. al., 1989) and Media Ecology Model (McLuhan, 1964). Technological acceptance model is one of the most influential research models on the studies of the determinants of information systems and information technology acceptance to predict intention to use and acceptance of information systems and information technology by individuals (Chen, 2011; Mohammed and Suleiman, 2013). The model explains why organization or individuals accept a particular technology, and it explained acceptance from three perspectives: Perceived ease of use, Perceived usefulness and Attitude towards the technology. The attitude of a user towards a system according to Chuttun (2009) is a major determinant of whether the user will actually use or reject the system. In like manner, the attitude of user is considered to be influenced by two major beliefs: Perceived usefulness and Perceived ease of use, with Perceived usefulness. The relevance of the model lies in the explanation why an innovation, which social media presents would be accepted or not by its potential users.

This theory is relevant to this study in the sense that, ICT facilities are useful and easy to use in book production. With regards to book production, ICT facilities can be used to improved book production (Beers, 2007; Dabbagh \& Bannan-Ritland, 2005). The capability of internet, for instance, has improved access to published resources, sales and distribution for public consumption. Having access to worldwide information resources on the net is a tremendous potential for improving educational quality. Furthermore, the capability of e-mail to support time and place, independent publisher-author and author-author communication is also a quality-improving potential. In addition, the capability of computer conferencing to support interactions among publishers, authors, general public as it relates to book publishing, provides opportunity for individualized and collaborative learning.

Another rationale for the use of ICT in book production relates to the cost-reduction potential of the tool. It is believed that, the capability of ICT facilities to support production, distribution and sales of information resources allows for the mass availability of educational resources. Moreover, the use of ICT can save travel time and other transaction costs for both the publishers and potential buyers or customers.

Media Ecology Model (MEM) explained the influence of technologies like radio, telephones, television among others, on the entire human communication process, 
establishing their social impact on the society. McLuhan (1964) opined that, societies are highly dependent on mediated technology and a society's social order and business development are based on its ability to key into that technology. This assertion can be clearly identified in the Nigerian book publishing operations. This is evident in the development of Internet as it changes the environment of book publishing as a major aspect of interactions among the publishers. The MEM theory was established on three fundamental assumptions: 1) Media infuse every act an action in society 2) Media fix our perceptions of the society and organizes our experiences 3) Media ties the world together. When applied to book publishing operations, the assumptions are that: 1) Publishers and authors infuse every act and actions in the society in the writing and publishing. 2) Publishers fix our perceptions and organize our experiences 3). The book publishing industry is a vital engine that drives the development of any society. It is believe that, when the theories are applied to book publishing operations, it then means that, society cannot escape the influence of technology and as such technology will remain central in all aspect of today's publishing operation.

\section{Literature Review}

Twenty-first centuries has revolutionized the publishing concept together with the processes of book production. Publishing refers to the dissemination of literature, music or information. Basically, it is the activity of making information available to the general populace. Traditionally, the term was restricted to printed materials such as books and newspapers, but with the advent of digital information systems and internet, it has expanded the scope to include electronic resources. Whereby, publishers now have electronic versions of books, periodicals, websites, blogs, and video games among others of their published products that can be accessed. From the foregoing therefore, publishing is a medium through which information is communicated to the general public

Information communication technology facilities is an emerging technology which the publishing industry has keyed into, particularly the computer, telecommunication and internet technologies have greatly impacted on the publishing industry globally through the introduction of facilities that enhances e-book, e-economic, low volume production, internet book distribution. Print-on-demand publications, emails, EDI and bar coding, CD-ROM, word processing packages among others.

In view of the above, Information communication technology facilities is applicable in all the aspect of the production and distribution in publishing. Especially in areas like promoting, distributing and marketing books with modern information communication technologies .A study carried out by Obinyan (2008) revealed that ICT facilities used for book processes by publishers were: scanners, computers, internet, digital cameras, fax machines, mobile phones, telephones (lines), telex, monochrome, photocopiers,, blackberry, www, and internet. ICT knowledge and skills are now seen as key resources and crucial tools for development of any society which the publishing industry has a greater role to play. These facilities are used for editing, communicating, storage, production and distribution of 
products. The media facilities removes physical production and distribution costs, together with the time involved aside being used to increase convenience for individuals. Many users now have browsers that restrict pop-ups and spam filters, which may also divert files and messages. (Smithers, 2019).

The advantages or benefits of these facilities are enormous. For instance, e-Books can be sold in million copies within a very short period. They can be easily accepted instantaneously worldwide, updated, revised, read, listened to and have colour or music added if need be. These facilities allow the publishers to enjoy the e-commerce privileges especially if they are on line. Products can be sold on time on websites or rather homes pages including advertising. Books and other items can also be sold through internet in net shop. It is estimated according to Zakari (2001) quoting Ross (2000) that, book sales on the internet through net bookshops are now $15 \%$ of the total books sold, with amazon.com, holding $80 \%$ of the market and barnarandnoble.com 10\%. Besides e-book, CD-ROM has added to advantage to publishing. Several e-books could be copied on CD-ROMS and made them available for sale in market. This had reduced the problems of strains on the eyesight, electricity power failure, portability, storage, conveyance or dissemination of information, and updating of the book content. Similarly, emails and telemarketing facilities uses telephone system such as the videophones to attract new customers worldwide while retaining existing ones. These facilities have the provision for recording and playing messages which could be used to advertise products and take orders. In fact emails has been further boosted with the introduction of multipurpose internet mail extensions (MIME) which has the ability to send messages electronically including formatted documents, photos, pictures, sound files and video files attachment. Thus, contact with authors and printers is made easy with emails. Publishers now maintain EDI and bar coding mechanism, where computer can exchange burned documents in a standard format. This helps to transmit documents to shippers, transporters, customers etc. with speedy economy as against sending bulk of papers through corner and postal agencies. Travel guide can easily be produced and updated with ease.

The barcode system assists to identify a significant product distinct from others with all the relevant information about it readily available on the computer. In fact, the trend in book publishing has given birth to audio books, e-books, e-publishing, Point on demand (Akinjogbin, 2009).

The Information Technology facilities had enabled those who are not skilled in information technology or computer to emerge as printers, especially in areas of desktop publishing where one person carries out publishing processes alone right in his bedroom. With the ICT facilities for publishing, the face of publishing industry is set to change. Future businesses will now be determined with the use of digital technologies. Investigation made by Smithers ( 2019) attested that, "in 2020, print products and their producers have real completion from alternative media for the first time since the invention of movable type" There is this trend where publishers and print buyers are now investing in new methods either 
to sell products or communicate with end users. With the new technologies, there are better, faster networks and new devices like e- readers, smart phones and tablets. Where publishers can provide contents for the devices and advertisers are exploring how to communicate with prospects and customers. From all indication, the world is becoming connected and print needs to re-access its position in the market as new alternatives are being presented with much marketing support. Of a truth, the traditional publishing industries has new competitors. Presently, ICT facilities allows easy posting of few characters to a high-quality video that has made everybody a publisher or reporter. In fact, the conventional distribution and retail channels had equally taken a new dimension. With downloads, the supplier is instantly paid for content via a credit card or pay pal-type transaction, and there is no investment in physical stock or distribution. This is an attractive model.. On the other hand, technologies for exploring the Internet and receiving content are developing rapidly. New e-reader devices are attracting a great deal of interest as alternatives to traditional print products. Though the text handling technology in print has developed over hundreds of years to provide many interesting type styles and design tools, to create appealing and easy-to-read pages and document, the present situation has brought about a unique link and code that allows a onetime download of the title electronically.

Google is becoming a significant player in publishing digital content. For instance, Google books has over 12 million books available for searching. Through its well-publicized negotiation with publishers and authors, Google can sell the full text of books, which probably are out of print. In areas of social media, Publishers, retailers, and book vendors are tapping into the technology where information are widely shared. This has become useful to publishers, advertisers, who are working to provide tailored content to appeal to individuals. larbolestier (2006) further collaborated that, electronic publishing facilitates easy revision of the text for more conventional monographs, where readers can communicate their corrections, additions and suggestions. Thereby makes editorial processes lots easier.

\section{Methodology}

Descriptive research design was adopted and the total population of the study comprised personnel from 150 publishing industries in Nigeria. The number of staff working in the publishing industries is a determinant. A sample size of 10 publishing industries and 546 personnel were used for the study using purposive sampling. The rationale for the choice was because; they have branches in all the state capitals of Nigeria. In addition, they have a long standing in the business of publishing. The publishing industries considered in this study were: African University Press (51), Evans Brothers Nig. Ltd (58), Africana First publisher Ltd (65), Bounty Press Ltd (33), HEBN publishers Plc.(75), Macmillan Nig. Pub. Ltd. (55), Learn Africa Plc. (50), Spectrum Books Ltd. (55), University Press (58), and West African Book (45).

The researcher used all the 546 personnel in the ten publishing industries that comprised the population for this study. Considering the research of this nature, the entire 
population was adopted because it was manageable in terms of cost and accessibility to the target population. Afolabi (1999) affirmed that, the entire population under study can be adopted if it is manageable in terms of cost and accessibility to subjects of the study. The executives, intermediate/senior and junior staff was considered in all the sample publishing industries in Nigeria. The rationale behind this adoption is that, the three categories of staff performed different functions in the publishing industries. The four point scale of questionnaire tagged: Relationship between information communication and Book production in publishing Industries in Nigeria. The administration of the copies of questionnaire was carried out by the researcher and five research assistants who were duly trained

Chi-Square was used to test Null hypotheses at 0.05 level of significance. While statistical Package for Social Sciences (SPSS version 20) tool was adopted for this study. The four (4) rating scale of Strongly Agree (SA) $=4$, Agree (A) $=3$, Disagree (D) $=2$, and Strongly Disagree $(\mathrm{SD})=1$ was adopted in the research instrument.

\section{Findings}

\section{Response Rate:}

Table 1 presents response rate of personnel from the ten publishing companies under study.

Table 1: Response Rate

\begin{tabular}{lllll}
\hline Publishing Companies & $\begin{array}{l}\text { Copies } \\
\text { QuestionnaireA } \\
\text { dministered }\end{array}$ & $\begin{array}{l}\text { of } \\
\text { Questionnaires } \\
\text { Retrieved }\end{array}$ & $\begin{array}{l}\text { of } \\
\begin{array}{l}\text { Percentage } \\
\text { Retrieved } \\
\text { questionnaires }\end{array}\end{array}$ & $\begin{array}{l}\text { of } \\
\text { African University press }\end{array}$ \\
\hline Africana First publisher Limited & 60 & 11 & 2.4 \\
\hline Bounty Press Limited & 30 & 50 & 10.8 \\
\hline Evans Brothers Nigerian Limited & 70 & 20 & 4.3 \\
\hline HEBN Publishers PLC & 50 & 61 & 13.2 \\
\hline Macmillan Nigerian Publishing Limited & 26 & 40 & 8.7 \\
\hline Learn Africa Plc. & 35 & 21 & 4.5 \\
\hline Spectrum Books Limited & 80 & 30 & 6.6 \\
\hline University Press PLC & 120 & 72 & 15.5 \\
\hline West African Book & 60 & 105 & 22.7 \\
\hline Total & 546 & 52 & 11.3 \\
\hline
\end{tabular}

A total of 546 copies of the questionnaire were administered to all staff of the ten publishing industries as reflected in the table. Out of this number, 462 (85\%) were completed, retrieved and found usable, giving the overall response rate of $85 \%$. While $15 \%$ was recorded as nonresponse rate. The high response rate could be attributed to the self- administration of the instrument by the researcher and the effort of the trained research assistants. Probably the simplicity of the questionnaire added to the high return rate.

\section{Characteristic of Respondents}

The response rate showed that 462 staff in ten publishing industries in Nigeria responded to the level of utilization of Information Communication Technology in book production. The demographic variables considered were: year of establishing the company, gender, and marital status, age range of respondent, designation/Rank and years of experience of staff respectively. 
Table 2: Year of Establishing Industries and Characteristics of Respondents

\begin{tabular}{|c|c|c|c|}
\hline VARIABLES & Options & Frequency & Percentage (\%) \\
\hline \multirow[t]{5}{*}{ Year of Establishing Publishing Industries } & $1951-1960$ & 105 & 22.7 \\
\hline & $1961-1970$ & 202 & 43.7 \\
\hline & $1971-1980$ & 102 & 22.1 \\
\hline & $1981-1990$ & 53 & 11.5 \\
\hline & Total & 462 & 100 \\
\hline \multirow[t]{3}{*}{ Gender } & Male & 279 & 60.4 \\
\hline & Female & 183 & 39.6 \\
\hline & Total & 462 & 100 \\
\hline \multirow[t]{3}{*}{ Marital Status } & Single & 158 & 34.2 \\
\hline & Married & 304 & 65.8 \\
\hline & Total & 462 & 100 \\
\hline \multirow[t]{6}{*}{ Age Range of respondent } & Below 30 years & 149 & 32.3 \\
\hline & $30-40$ years & 190 & 41.1 \\
\hline & $41-50$ years & 88 & 19 \\
\hline & $51-60$ years & 29 & 6.3 \\
\hline & Above 60 years & 6 & 1.3 \\
\hline & Total & 462 & 100 \\
\hline \multirow[t]{7}{*}{ Designation / Rank } & Editor & 164 & 35.5 \\
\hline & Production Manager & 30 & 6.5 \\
\hline & Admin Manager & 29 & 6 \\
\hline & Marketing Manager & 34 & 3 \\
\hline & Accountant & 52 & 11.3 \\
\hline & Others & 153 & 33.1 \\
\hline & Total & 462 & 100 \\
\hline \multirow[t]{4}{*}{ Years of Experience } & $1-4$ years & 275 & 59.5 \\
\hline & $5-9$ years & 129 & 27.9 \\
\hline & 10 years and above & 58 & 12.6 \\
\hline & Total & 462 & 100 \\
\hline
\end{tabular}


Table 3a: Cross-Tabulation of Utilization of Communication Facilities on Book Production in Nigeria

\begin{tabular}{lccccccc}
\hline Source of variable & \multicolumn{7}{c}{ Book production in Nigeria } \\
\cline { 2 - 7 } & & $1-100$ & $101-200$ & $201-500$ & Above 500 & Total \\
\hline \multirow{3}{*}{ Utilization of Communication facilities } & $\mathrm{SA}$ & 60 & 39 & 38 & 22 & 159 \\
\cline { 2 - 7 } & $\mathrm{A}$ & 216 & 24 & 28 & 15 & 283 \\
\cline { 2 - 7 } & $\mathrm{D}$ & 7 & 2 & 2 & 1 & 1 & 4 \\
\cline { 2 - 7 } & $\mathrm{SD}$ & 2 & 2 & 69 & 40 & 462 \\
\cline { 2 - 7 } & Total & 285 & 68 & &
\end{tabular}

Results in table 2a: Shows that, 285(61.7\%) production rate by the publishers were within the range of 1-100 books, 68(14.9\%) were within 201-500, while 40(8.7\%) were within 5001 and above. The responses revealed that, majority of the publishing companies in Nigeria could only produce 100 books in a year. The researcher wishes to say that, the production rate is very low compare to the population of Nigerians.

Table 3b: Chi - Square Result of Utilization of Communication Facilities on Book Production in Nigeria

\begin{tabular}{lcccc}
\hline Source of Variable & D.F & $\mathbf{X}_{\text {cal }}^{2}$ & $\mathbf{P}$ - value & $\begin{array}{c}\text { Decision } \\
\mathbf{P}<\mathbf{0 . 0 5}\end{array}$ \\
\hline $\begin{array}{l}\text { Utilization of ICT communication on book } \\
\text { production in Nigeria }\end{array}$ & 9 & 69.6 & 0.000 & Reject $\mathrm{H}_{0}$
\end{tabular}

The contingency table and the Chi - square test table indicated that there was a significant relationship between the utilization of Information Communication Technology facilities and book production in Nigeria because $\left(\chi_{\text {cal }}^{2}=69.9\right)$. This decision was taken because the calculation, $\chi^{2}$ of 69.6 is greater than P- value of 0.000 at 0.05 level of significant with 9 degree of freedom. This decision was reached because the null hypothesis which states that "there is no significant relatiobetween the utilization of Information Communication Technology facilities and book production in Nigeria" was rejected. This implies that if the facilities are utilized properly, it would lead to an improvement and increment in the production of books in Nigeria. The result therefore revealed that, using information communication facilities improved quality of communication and production and equally increased productivity in publishing industries in Nigeria. 
Table 4a: Cross-tabulation on Utilization of Technology facilities on Book Production in Nigeria

\begin{tabular}{|c|c|c|c|c|c|c|}
\hline \multirow[t]{2}{*}{ Source of variable } & \multicolumn{6}{|c|}{ Book production in Nigeria } \\
\hline & & $1-100$ & $101-200$ & $201-500$ & Above 500 & Total \\
\hline \multirow{5}{*}{ Utilization of Technology facilities } & SA & 142 & 27 & 65 & 20 & 254 \\
\hline & A & 133 & 36 & 0 & 16 & 185 \\
\hline & $\mathrm{D}$ & 4 & 2 & 4 & 3 & 13 \\
\hline & SD & 6 & 3 & 0 & 1 & 10 \\
\hline & Total & 285 & 68 & 69 & 40 & 462 \\
\hline
\end{tabular}

Table 4b: Chi - Square Result on Utilization of Technology Facilities on Book Production in Nigeria

\begin{tabular}{llllllc}
\hline Source of Variable & & D.F & $\mathbf{X}_{\text {cal }}^{2}$ & P - value & $\begin{array}{c}\text { Decision } \\
\mathbf{P}<0.05\end{array}$ \\
\hline $\begin{array}{l}\text { Utilization of Technology } \\
\text { Production in Nigeria }\end{array}$ & ICT on Book & 9 & 67.76 & 0.000 & Reject $\mathrm{H}_{0}$
\end{tabular}

The cross tabulation and Chi - square test table presented above shows that there was a significant relationship between the Utilization of Technology facilities and Book Production in Nigeria because $\left(\chi_{\text {cal }}^{2}=67.76\right)$. This decision was taken because the calculation $\chi^{2}$ of 67.76 was greater than P- value of 0.000 at 0.05 level of significant with 9 degree of freedom, and P- Value $=0.00$ was less at 0.05 level of significant. This decision was reached because the null hypothesis which states that "there is no significant relationship between the utilization of technology facilities on book production in Nigeria" was rejected. This implies that if technology facilities were utilized properly, it would lead to an improvement and increment in the production on books in Nigeria. Hence, the result from the analysis revealed that, the use of technological facilities in book production had improved quality of production and at the same time increase productivity of books published by Nigerian publishing industries

\section{Discussion of Results}

Findings on the utilization of communication facilities for book production in Nigeria publishing industries revealed that, it enhances editorial procedures, advertisement, announcement of forthcoming titles and communication with the authors and among publishers in Nigeria and abroad. On the utilization of technology facilities for book production by publishing industries in Nigeria, the findings revealed that, it facilitates speed in publishing activities, easy retrieval of graphics and mass production of finished books. This position was agreed by Ogunsola (2004) who attested that, Technology facilities like Internet had made it possible for easy accessibility and retrieval of information resources much easier. Similarly, Ehikhamenor (2003) further agreed to the speed, skills, quality of production, better page layout, good image, improvement in picture resolution and general graphics as benefits 
of using technology facilities in book production. This implies that, the quality of book production in Nigeria publishing industries has greatly improved as their counterpart in abroad.

Hypotheses formulated for the study showed significant relationship between the utilization of Communication Technology facilities on book production in Nigeria. This finding is in agreement with TAM and MEM theories. This indicates that, Nigerian publishers had accepted and adopted the use of ICT facilities for book production in Nigeria publishing industry. Hence using ICT facilities by the publishers has enabled them to harness the perceptions and experiences of the society in book production. It is presume that, the society cannot shy away with the influence of ICT in book productions, and will remain central in all aspect of modern publishing operations in Nigeria. Actions taken by Nigerian publishers had further made book publishing a vital engines that will aid in the development of the society at large (Davies, 1989 and McLuham, 1964).

This finding implies that, the Nigerian publishers had accepted the use of ICT facilities to communicate to their clients as against the traditional methods. It then implies that, communication between publishers to authors or booksellers or vice versa had been improved and lot easier. This finding confirmed the works of Taiwo and John (2001), Okoye (2000) and Area (2009) as they all corroborate that, communication from the editor to authors and submission of corrected manuscript are carried out online. This has further enhanced prompt delivery of products. Also internet facility was used for fact checking, referencing and research purposes. Now editors can work conveniently even outside their offices. With the acceptance of Information Communication Technology facilities by the publishers for book production, by implication there is a great improvement in communication between authors and publishers. Also the issue of delay editing authors work has been drastically reduced.

The second hypothesis showed significant relationship between the utilization of Technology facilities on book production in Nigeria. This implies that, publishers in Nigeria had accepted the usage of technology facilities which by implications had led to the enhancement in the production and distribution of books by Nigeria publishing industries.

\section{Conclusion}

Based on the findings of the study, the society can no longer escape the influence of ICT on book production. There is a significant relationship between the use of ICT and book production in Nigeria publishing industry. Using ICT facilities by the publishers had enable them to harness the perceptions and experiences of the society in book production and had been incorporated into all aspects of modern publishing operations in Nigeria. Actions taken by Nigerian publishers had further made book publishing a vital engines that will aid in the development of the society at large.

Nigerian publishers had accepted the use of ICT facilities to communicate to their clients as against the traditional methods. Communication between publishers to authors or 
booksellers or vice versa, editorial procedures, advertisement had been improved and lot easier. Uses of ICT facilities for book production equally facilitated sales and distribution of books locally and internationally online and ensured free access to information. It further helped in the announcement of forthcoming titles to the general public with less stress.

\section{Recommendations}

Based on the findings and conclusion reach, the study proffer the following practical recommendations:

1. For efficient information communication from publishers to authors, booksellers and customers, management of the publishing industry should maintain relevant information databases on clients and to have a robust catalogues and stock lists widely circulated for public consumption. Also, publishers should have a functioning channel for effective communication and directory of all customer's transactions in order to keep them abreast of new productions either through their phones, e-mails, websites, YouTube, blogs or whatsapp.

2. With the acceptance and adoption of ICT in book production, the management of the publishing industry should ensure that, production are of good quality and must be maintained by investing and acquiring high grade modern ICT-based publishing equipment meant for book production.

\section{References}

Abubakar, M. K. (2010) ICT knowledge and skills among students of library and information science in Umaru Musa Yar'adua University, The Information Manager, 10 (1\&2), 40

Achebe, N. E. E. (2005) the status of ICT in Nigerian Public Libraries. Coal City Libraries $2(1 \& 2), 16$

Afolabi, M. (1999). Research methodology, in Alkaleri, A. U. (Edds). Fundamentals of research in Librarianship. Kaduna: Academic Press, 29-40.

Aina, L. O. (2004). Library and Information services text for Africa. Ibadan: Third World Information services Limited. Nigeria. 41-58.

Areo, A. (2009) A Guide To Book Writing And Publishing. Ibadan: Agbo Area publishers.

Chen, S. \& Li, C. (2011). Recent research in Technology Acceptance Model: A literature review. Australian Journal of Business Management Research. Vol.1 (9).

Chuttur, M. (2009). Overview of the Technology Acceptance Model, origin, development and future directions. Indiana University, USA.

Davis, F. D. (1989) Perceived Usefulness, Perceived ease of use, and User Acceptance of 
Information Technology. MIS Quarterly 13 (3), 319-342.

Egbunu, A. J. (2004). The application of computer technology to selected publishing companies in Nigeria. Unpublished MLS these, Bayero University, Kano. P.14

Ehikhemanor, F. A. (2001) Automation in Nigerian University Libraries: Progress or mirage? Nigerian Library Information Science Review. 8(1), 1-11.

Ihebuzor, L. A. \& Odu, A. S. (2016). The place of information, communication and Technology (ICT) in book publishing operations in Nigeria: Singaporean Journal on Business Economics, and Management Studies, 4 (11).

Mohammed, S. \& Suleiman, H. (2013). Knowledge and utilization of social media by students of Nuhu Bamali Polytehnic Zaria, Nigeria. In the Nigerian Journal of Communication, 2(1).

Mohammed, Z. (2001). The book industry in national development: Nigerian perspectives. Samaru Journal of Information Studies. 1(1)

Obinyan, G. A. (2008) Location of Publishing firms. Information and Communication Technologies and use of language as factors affecting sustainable development of book publishing in Nigeria. Communicate. Journal of Library and Information Sciene. 11(1), 9.

Okoye, I. (2000). Newspaper Editing and Production: The Computer Age. Lagos: Mbeyi \& associates Ltd.

Smithers, P. (2019). New devices and means of consuming content are changing the face of the publishing Industry. NCC/Document/ICT1020Publishing\% 202019.pdf

Sogbein, O. (2008). Report: Executive summary for 2007. The Publisher. 1. 20-26.

Taiwo, A. A. and John, E. N. (2011). The fading distinctiveness in the role of author, publisher, and bookseller in book development: Implications for the emerging information society and Nigerian book industry. Jewel Journal of Librarianship. 3.

Understanding book production and the processes involved. https://www.quickfox.co.za>book... Retrived on 15/5/2020. 